\title{
Does Ability to Identify Odors Differ Among Clinical Subtypes of Parkinson's Disease?
}

\author{
Parkinson Hastalı̆̆ı Klinik Subtipleri Arasında Kokuları Tanıma Yeteneği Farklılık Gösterir mi?
}

Tuba Aydemir Özcan, Serkan Özben*, Hüsniye Aylin Hakyemez**, Mithat Bedir**, Emel Oğuz Akarsu**, Feriha Özer, Lütfü Hanoğlu***, Gülüm Ivgin Bayraktar*****

Ordu University, School of Medicine, Department of Neurology, Ordu, Turkey

*Kafkas University, Medical Faculty, Department of Neurology, Kars, Turkey

**Haseki Training and Research Hospital, Department of Neurology, Istanbul, Turkey

***Istanbul Medipol University, School of Medicine, Department of Neurology, Istanbul, Turkey

****Haseki Training and Research Hospital, Department of Otolaryngology and Head \& Neck Surgery, Istanbul, Turkey

\section{Summary}

Objective: Parkinson's disease (PD) is characterized by motor dysfunction, and is also a non-motor disorder. Olfactory dysfunction (OD) is a non-motor symptom in PD. In this study, we aimed to investigate whether OD varies among subtypes of PD.

Material and Method: Patients comprised 28 patients with idiopathic PD ( 23 male and 5 female) with a mean age of $64.96 \pm 7.49$ years. The patients were divided into tremor-dominant type (TDT), akinetic-rigid type (ART) and mixed type (MT) by means of part III of Unified Parkinson's Disease Rating Scale. Patients were asked whether they had a relative with tremor or PD. University of Pennsylvania Smell Identification Test-40 (UPSIT-40) was used to test olfactory function. Patients with any factor that may influence olfactory function were excluded.

Results: Fourteen patients were classified as TDT, 12 as ART, and 2 as MT. There were no significant differences in mean age, UPDRS part III, and UPDRS total scores. The UPSIT scores were the highest in the MT group and lowest in the ART group, but there was no statistically significant difference.

Discussion: Our results do not prove a difference in OD between subtypes of PD, but suggest that ART patients might have a poor ability to identify odors. (Turkish Journal of Neurology 2012; 18:151-154)

Key Words: Parkinson's disease, clinical subtypes, olfactory dysfunction

\section{Özet}

Amaç: Parkinson hastalığı motor disfonksiyon ile karakterize olmakla birlikte, aynı zamanda nonmotor bir hastalıktır. Olfaktor disfonksiyon (OD), PH'de görülen nonmotor bir semptomdur. Bu çalışmada, $\mathrm{PH}$ alt tiplerinde OD disfonksiyonda farklılık varlığını araştırmayı amaçladık.

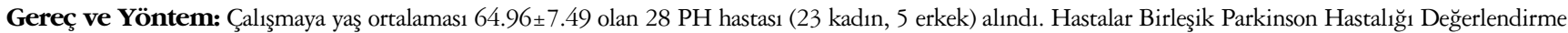
Ölçeği bölüm III’e göre tremor baskın (TBT), akinetik-rijid (ART) ve miks tip (MT) olarak gruplara ayrıldı. Hastalara tremor veya PH li yakınları olup olmadığı soruldu. OD'yi değerlendirmek üzere "University of Pennsylvania Smell Identification Test-40 (UPSIT)" kullanıldı. Olfaktor fonksiyonunu etkileyebilecek faktörlere sahip hastalar çalışma dışı bırakıldı.

Bulgular: Ondört hasta TBT, 12 hasta ART ve 2 hasta MT grubuna dahil oldu. Yaş ortalaması, BPHDÖ bölüm III ve BPHDÖ toplam puanı gruplar arasında farklılık göstermedi. UPSIT skorları MT grubunda en yüksek iken ART grubunda en düşüktü, ancak istatistik açısından anlamlı bir farklılık gözlenmedi.

Sonuç: Sonuçlarımız PH alt tipleri arasında OD farklılı̆̆ı göstermemekle birlikte, ART grubundaki hastaların koku tanımada daha düşük performans gösterebileceğini düşündürmektedir. (Türk Nöroloji Dergisi 2012; 18:151-154)

Anahtar Kelimeler: Parkinson hastalı̆̆ $\breve{1}_{1}$ klinik alt tipleri, olfaktor disfonksiyon

Address for Correspondence /Yazışma Adresi: Tuba Aydemir Özcan MD, Ordu University, School of Medicine, Department of Neurology, Ordu, Turkey

Gsm: +90 5334796529 E-mail: dr_aydemir@yahoo.com

Received/Geliş Tarihi: 05.08.2012 Accepted/Kabul Tarihi: 02.12.2012 


\section{Introduction}

Parkinson's disease (PD) is characterized by motor dysfunction, and is also a non-motor disorder. The non-motor symptom complex of PD includes olfactory and autonomic dysfunctions, sleep disorders, sensory symptoms, gastrointestinal symptoms, visual hallucinations $(\mathrm{VH})$ and other neuropsychiatric symptoms $(1,2)$.

Olfactory dysfunction has also been reported in other synucleopathies (3), whereas non-synucleopathies tend to present with intact olfactory function (4). Approximately $90 \%$ of PD patients have reported olfactory dysfunction (OD) as a potential preclinical marker of motor symptoms $(5,6)$. It was also reported that asymptomatic relatives with OD of patients with PD subsequently became symptomatic (7).

In postmortem studies, it was shown that Lewy bodies accumulated in the olfactory bulb (OB), anterior olfactory nucleus (AON), piriform cortex, amygdaloid complex, entorhinal cortex and hippocampal formation $(8,9,10,11,12)$. Early degeneration of extranigral neurons in $\mathrm{OB}$ and $\mathrm{AON}$ seems to be leading to OD as a preclinical symptom (1).

In $\mathrm{PD}$, clinical subtypes are classified based on predominant symptoms: tremor-dominant type (TDT), akinetic-rigid type (ART) and mixed type (MT). Recent studies showed varying findings between subtypes of PD. TDT patients exhibit fewer depressive symptoms and PD progress is slower than ART (13). Positive family history of PD is more frequent in TDT than ART (14). The sympathetic autonomic system is less impaired in TDT (15).

The clinical follow-up and autopsy showed that the course of PD is more favorable in TDT than MT and ART, respectively (16). Ondo et al. reported that TDT patients with a family history of tremor had less olfaction loss than the patients with a negative family history (17).

In this study, we aimed to investigate whether OD varies among clinical subtypes of PD.

\section{Materials and Methods}

\section{Patients}

Patients with PD were recruited from Haseki Training and Research Hospital outpatient clinic of movement disorders. The study was approved by the local ethics committee and all the patients provided written informed consent before being included into the study.

Twenty-eight patients with idiopathic PD (23 male and 5 female) were enrolled into the study; patients' age ranged from 48 to 79 (mean \pm SD, $64.96 \pm 7.49$ ) years. PD was diagnosed based on the Criteria of the United Kingdom Brain Bank (18) by a specialist. Hoehn \& Yahr Scale $(\mathrm{H} \& \mathrm{Y})$ was used for disease staging (19) and Unified Parkinson Disease Rating Scale (UPDRS) (20) was used to determine the clinical severity. Mini Mental State Examination (MMSE) was used to screen cognitive impairment (21).

The patients were divided into TDT, ART and MT by means of part III of UPDRS similarly described by other researchers (22). The tremor score was obtained from the sum of UPDRS items 20 (tremor at rest) and 21 (action or postural tremor of hands). The non-tremor score was derived from UPDRS items 18 (speech), 19 (facial expression), 22 (rigidity), 27 (arising from chair), 28 (posture), 29 (gait), 30 (postural stability), 31 (body bradykinesia and hypokinesia). If the tremor score was $\geq 2 \mathrm{x}$ the non-tremor score, the patient was classified as TDT. If the non-tremor score was $\geq 2 \mathrm{x}$ the tremor score, the patient was classified as ART. The remaining patients were classified as MT. Fourteen, 12 and 2 patients were assigned to the TDT, ART, and the MT subgroups, respectively.

Patients with any factor that may influence olfactory function were excluded from the study. Patients with head trauma, nasal polyposis, nasal sinus disease, allergic rhinitis, severe septal deviation and with a history of olfactory diseases were evaluated by a head and neck surgery specialist and were not enrolled in the study. None of the patients had a history of epilepsy and stroke. Patients were asked whether they had a relative with tremor or $\mathrm{PD}$.

University of Pennsylvania Smell Identification Test-40 (23) was used to test olfactory function. The test included 40 odorants. The odors were released by scratching the related point on the paper with a pen tip. The participant chose one of four possible alternative answers. Patients were instructed to make their best guess if they could not identify an odor.

\section{Statistical analysis}

ANOVA was used for group comparison of family history, age, gender and olfaction scores between three groups. For correlations, Pearson's correlation was used in case of normally distributed data, Spearman's correlation in case of not normally distributed data. Chi-square test for independence was used between genders and subtypes.

\section{Results}

The characteristics of clinical subtypes are shown in Table 1. Fourteen patients were classified as TDT, 12 as ART, and 2 as MT. There were no significant differences in mean age, UPDRS part III, UPDRS total, H\&Y, MMSE, or UPSIT scores among the clinical subtypes. No correlation was found between UPSIT scores, UPDRS part III scores, UPDRS total scores, and H\&Y scores. Nine patients in the TDT group, nine patients in the 
Table 1. The characteristics of clinical subtypes

\begin{tabular}{|c|c|c|c|c|}
\hline & TDT $(n=14)$ & $\operatorname{ART}(n=12)$ & MT $(n=2)$ & $\mathrm{p}$ \\
\hline Age (years) & $65.07 \pm 6.58$ & $65.33 \pm 9.20$ & $62.0 \pm 1.41$ & 0.85 \\
\hline Gender (female/male) & $4 / 10$ & $1 / 11$ & $0 / 2$ & 0.33 \\
\hline H\&Y Stage & $1.71 \pm 0.46$ & $1.58 \pm 0.51$ & $1.50 \pm 0.70$ & 0.73 \\
\hline UPDRS total & $15.7 \pm 1.96$ & $14.42 \pm 3.02$ & $13.50 \pm 0.70$ & 0.26 \\
\hline UPDRS part III & $11.07 \pm 1.81$ & $10.58 \pm 2.27$ & $10 \pm 0$ & 0.70 \\
\hline UPSIT & $15.79 \pm 4.69$ & $14.33 \pm 4.20$ & $19.50 \pm 7.77$ & 0.33 \\
\hline Presence of family history & $3 / 11$ & $1 / 11$ & $0 / 2$ & 0.56 \\
\hline MMSE scores & $25.64 \pm 2.09$ & $26.92 \pm 1.62$ & $25.50 \pm 2.12$ & 0.22 \\
\hline
\end{tabular}

H\&Y: Hoehn and Yahr Scale; UPDRS: Unified Parkinson's Disease Rating Scale; UPSIT: University of Pennsylvania Smell Identification Test-40, MMSE: Mini Mental State Examination Test

ART group and one patient in the MT group were considered as having hyposmia. Four male patients had a positive family history. One of these patients was in the ART group and his relative (mother's brother) had PD. The other three patients with a positive family history were in the TDT group, and two of them had a relative with essential tremor (one the mother, the other the mother's brother), while the last patient had a relative (the father's brother) with PD.

\section{Discussion}

This study showed no significant differences in olfaction scores among PD subtypes. Although the UPSIT scores were highest in the MT group and lowest in the ART group, there was no statistically significant difference and there was no difference in age, gender or disease staging.

Verbaan et al. demonstrated that dopamine transporter binding in the striatum correlated with olfactory impairment in patients with early PD (24). Lijima et al. reported that patients with TDT had better olfactory function than patients with ART. They suggested these findings mean that patients with severe olfactory disturbance have marked degeneration of the nigrostriatal dopaminergic neurons. Stern et al. found that UPSIT scores were higher in the TDT subtype (25). In contrast, other studies have found no difference in olfactory function among PD subtypes $(22,26)$. Spiegel et al. demonstrated higher N-(3fluoropropyl)-2ß-carbomethoxy-3ß-(4-iodophenyl) nortropane (FP-CIT) uptake in the TDT group than ART and MT groups (27). These suggested that the non-nigrostriatal deficit of the dopaminergic system may play a role in TDT, and patients exhibiting low performance in olfactory tests in the early stage might be representing a poor prognosis. Therefore, the clinical outcome in TDT might be expected due to the least biochemical abnormalities. However, in contrast to most previous studies, in our study we did not find a significant difference between subgroups of PD for the ability to identify odor. This finding may be related to the small number of patients in our subgroups. Differing results of the studies may also be related to the absence of any accepted definition of the subgroups. Similar to our results,
Ondo et al. did not find a difference between TDT and non-TDT patients. However in their study TDT patients with a positive family history showed better olfaction scores than the patients without a history of tremor (17). In our study, three of four patients with positive family history were in the TDT group and, two of them had a family history of ET. Interestingly, our four patients with a positive family history were male. Similar male dominance for TDT patients is also reported by Ondo et al (17). The reason for this gender dominance remains unclear. Likewise, association between PD and ET is not noticeable. TDT patients might more frequently have ET relatives $(28,29,30)$. Moreover, thalamic stimulation have similar efficacy in PD and ET $(31,32,33)$.

The underlying mechanism of the differences in olfactory function may lie in properties of the clinical subtypes of PD. Recent studies concluded that clinical subtypes of PD differ according to age at onset and positive family history. Besides these features it is suggested that the accompanying dementia, disease progression and response to therapy might depend on the subtype of PD $(34,35,36)$. Korchounov et al. found that positive family history of PD was a risk factor for the development of PD in patients with TDT and early onset ART, and they suggested that environmental factors might play a pathogenetic role for MT (14). In another study, it is suggested that there is an autosomal dominant inheritance in TDT, and autosomal recessive inheritance in ART (37). Neuropathological and neurochemical differences are also reported between clinical subtypes. While in patients with TDT medial substantia nigra and the retrorubral field are mainly affected, in patient with ART the lateral substantia nigra is predominantly affected $(38,39,40)$. Positron emission tomography (PET) studies demonstrate that TDT patients showed increased metabolic rates in thalamus and pons, whereas there was nigrostriatal deficit in ART patients $(40,41)$.

The main limitations of our study are as follows; 1 ) the small number of the patient groups and the unequal distribution of our cases reducing the power of our statistical analysis, and 2) family history of the patients not being confirmed by neurological examination, but only being concluded on the basis of medical history. 
In summary, the clinical subtypes of PD as characterized by the cardinal symptoms (TDT, ART, MT) did not differ to identify odors; on the other hand, ART patients showed not significant but lower UPSIT scores than TDT or MT patients. Our results did not prove a difference in OD between subgroups of PD, but suggested that ART patients might have a poor ability to identify odors. Future researches would be needed to evaluate this association.

\section{References}

1. Chaudhuri KR, Healy DG, Schapira AH; National Institute for Clinical Excellence. Non-motor symptoms of Parkinson's disease: diagnosis and management Lancet Neurol 2006;5:235-45.

2. Chaudhuri KR, Yates L, Martinez-Martin P. The non-motor symptom complex of Parkinson's disease: time for a comprehensive assessment. Curr Neurol Neurosci Rep 2005;5:275-83.

3. Boeve BF, Silber MH, Ferman TJ, Lucas JA, Parisi JE. Association of REM sleep behavior disorder and neurodegenerative disease may reflect an underlying synucleinopathy. Mov Disord 2001;16:622-30.

4. Khan NL, Katzenschlager R, Watt H, Bhatia KP, Wood NW, Quinn N, et al. Olfaction differentiates parkin disease from early-onset parkinsonism and Parkinson disease. Neurology 2004;62:1224-6.

5. Doty RL, Stern MB, Pfeiffer C, Gollomp SM, Hurtig HI. Bilateral olfactory dysfunction in early stage treated and untreated idiopathic Parkinson's disease. J Neurol Neurosurg Psychiatry 1992;55:138-42.

6. Ponsen MM, Stoffers D, Booij J, van Eck-Smit BL, Wolters ECh, Berendse HW. Idiopathic hyposmia as a preclinical sign of Parkinson's disease. Ann Neurol 2004;56:173-81.

7. Montgomery EB Jr, Baker KB, Lyons K, Koller WC. Abnormal performance on the PD test battery by asymptomatic first-degree relatives. Neurology 1999;52:757-62.

8. Del Tredici K, Rüb U, De Vos RA, Bohl JR, Braak H. Where does parkinson disease pathology begin in the brain? Neuropathol Exp Neurol 2002;61:413-26.

9. Ross GW, Abbott RD, Petrovitch H, Tanner CM, Davis DG, Nelson J, et al. Association of olfactory dysfunction with incidental Lewy bodies. Mov Disord 2006;21:2062-7.

10. Huisman E, Uylings HB, Hoogland PV. A $100 \%$ increase of dopaminergic cells in the olfactory bulb may explain hyposmia in Parkinson's disease. Mov Disord 2004;19:687-92.

11. Silveira-Moriyama L, Holton JL, Kingsbury A, Ayling H, Petrie A, Sterlacci W, et al. Regional differences in the severity of Lewy body pathology across the olfactory cortex. Neurosci Lett 2009; 453:77-80.

12. Braak H, Del Tredici K, Bratzke H, Hamm-Clement J, Sandmann-Keil D, Rüb U. Neurobiol Aging 2003;24:197-211.

13. Lewis SJ, Foltynie T, Blackwell AD, Robbins TW, Owen AM, Barker RA. Heterogenity of Parkinson's disease in the early clinical stages using a data driven approach. J Neurol Neurosurg Psychiatry 2005;76:343-8

14. Korchounov A, Schipper HI, Preobrazhenskaya IS, Kessler KR, Yakhno NN. Differences in age at onset and familial aggregation between clinical types of idiopathic Parkinson's disease. Mov Disord 2004;19:1059-64.

15. Mesec A, Sega S, Kiauta T. The influence of the type, duration, severity and levodopa treatment of Parkinson's disease on cardiovascular autonomic responses. Clin Auton Res 1993;3:339-44.

16. Rajput AH, Voll A, Rajput ML, Robinson CA, Rajput A. Course on Parkinsons disease subtypes. Neurology 2009;73:206-12.

17. Ondo WG, Lai D. Olfaction testing in Patients with tremor-dominant Parkinsons disease: is this a distinct condition? Mov Disord 2005;20:471-5.

18. Saito S, Ayabe-Kanamura S, Takashima Y, Gotow N, Naito N, Nozawa T, et al. Development of a smell identification test using a novel stick-type odor presentation kit. Chem Senses 2006;31:379-91.
19. Hoehn MM, Yahr MD. Parkinsonism: onset, progression, and mortality. Neurology 1967;17:427-42.

20. Fahn S, Elton R. Unified Parkinson's disease rating scale. In: Fahn S, editor. Recent Developments in Parkinson's Disease, vol. II. New Jersey: MacMillan Healthcare Information; 1987.p.153-63.

21. Güngen C, Ertan T, Eker E, Yaşar R, Engin F. Standardize Mini Mental Test'in Türk Toplumunda Hafif Demans Tanısında Geçerlilik ve Güvenilirliği. Türk Psikiyatri Dergisi 2002;13:273-81.

22. Spiegel J, Hellwig D, Samnick S, Jost W, Möllers MO, Fassbender K, et al. Striatal FP-CIT uptake differs in the subtypes of early Parkinson's disease. J Neural Transm 2007;114:331-5.

23. Doty RL, Shaman P, Dann M. Development of the University of Pennsylvania Smell Identification Test: a standardized microencapsulated test of olfactory function. Physiol Behav 1984;32:489-502.

24. Verbaan D, Boesveldt S, van Rooden SM, Visser M, Marinus J, Macedo MG, et al. Is olfactory impairment in Parkinson disease related to phenotype or genotypic characteristics? Neurology 2008;71:1877-82.

25. Stern MB, Doty RL, Dotti M, Corcoran P, Crawford D, McKeown DA, et al. Olfactory function in Parkinson's disease subtypes. Neurology 1994;44:266-8.

26. Hughes AJ, Daniel SE, Blankson S, Lees AJ. A clinicopathologic study of 100 cases of Parkinsons disease. Arch Neurol 1993;50:140-8.

27. Spiegel J, Hellwig D, Samnick S, Jost W, Möllers MO, Fassbender K, et al. Striatal FP-CIT uptake differs in the subtypes of early Parkinson's disease. J Neural Transm 2007;114:331-5.

28. Payami H, Larsen K, Bernard S, Nutt J. Increased risk of Parkinson's disease in parents and siblings of patients. Ann Neurol 1994;36:659-61.

29. Lang A, Kierans C, Blair R. Association between essential tremor and Parkinson's disease. Ann Neurol 1986;19:306.

30. Louis ED, Levy G, Mejia-Santana H, Cote L, Andrews H, Harris J, et al. Risk of action tremor in relatives of tremor-dominant and postural instability gait disorder PD. Neurology 2003;61:931-6.

31. Ondo W, Jankovic J, Schwartz K, Almaguer M, Simpson RK. Unilateral thalamic deep brain stimulation for refractory essential tremor and Parkinson's disease tremor. Neurology 1998;51:1063-9.

32. Koller W, Pahwa R, Busenbark K, Hubble J, Wilkinson S, Lang A, et al. High-frequency unilateral thalamic stimulation in the treatment of essential and parkinsonian tremor. Ann Neurol 1997;42:292-9.

33. Deiber MP, Pollak P, Passingham R, Landais P, Gervason C, Cinotti L, et al. Thalamic stimulation and suppression of parkinsonian tremor. Evidence of a cerebellar deactivation using positron emission tomography. Brain 1993;116:267-79.

34. Levy G, Tang MX, Cote LJ, Louis ED, Alfaro B, Mejia H, et al. Motor impairment in PD: relationship to incident dementia and age. Neurology 2000;55:539-44.

35. Jankovic J, Kapadia AS. Functional decline in Parkinson's disease. Arch Neurol 2001;58:1611-5.

36. Jankovic J, McDermott M, Carter J, Gauthier S, Goetz C, et al. Variable expression of Parkinson's disease: a baseline analysis of the DATATOP cohort. Neurology 1990;40:1529-34.

37. Barbeau A, Roy M. Familial subsets in idiopathic Parkinson's disease. Can J Neurol Sci 1984;11:144-50.

38. Jellinger KA. Post-mortem studies in Parkinson's disease-is it possible to detect brain areas for specific symptoms? J Neural Transm Suppl 1999;56:1-26

39. Vingerhoets FJ, Schulzer M, Calne DB, Snow BJ. Which clinical sign of Parkinson's disease best reflects the nigrostriatal lesion? Ann Neurol 1997;41:58-64.

40. Antonini A, Moeller JR, Nakamura T, Spetsieris P, Dhawan V, Eidelberg D. The metabolic anatomy of tremor in Parkinson's disease. Neurology 1998;51:803-10.

41. Otsuka M, Ichiya Y, Kuwabara Y, Hosokawa S, Sasaki M, Yoshida T, et al. Differences in the reduced 18F-Dopa uptakes of the caudate and the putamen in Parkinson's disease: correlations with the three main symptoms. J Neurol Sci 1996;136:169-73. 